\title{
EFFECTS OF DIFFERENT NITROGEN DOSES ON YIELD AND QUALITY TRAITS OF COMMON SUNFLOWER (Helianthus annuus L.)
}

\author{
Volkan GUL*, Kemalettin KARA \\ Ataturk University, Faculty of Agriculture, Department of Field Crops, Erzurum, TURKEY \\ *Corresponding author: volkangul555@gmail.com
}

Received: 03.06.2015

\begin{abstract}
The present study was conducted to determine the effect of nitrogen doses $\left(0,3,6,9,12\right.$ and $\left.15 \mathrm{~N} \mathrm{~kg} \mathrm{da}^{-1}\right)$ on yield and quality traits of common sunflower (Helianthus annuus L.) cultivars (Isera, C-70165 and Teknosol) with different growth periods under ecological conditions of Erzurum Province of Turkey in 2011 and 2012. Experiments were carried out in the Randomized Complete Blocks Design with three replications. Plant height, head diameter, kernel ratio, seed yield, thousand seed weight, oil yield, oil content, protein content and harvest index were investigated. The highest seed yield $\left(341.1 \mathrm{~kg} \mathrm{da}^{-1}\right)$, thousand seed weight $(65.2 \mathrm{~g})$ and head diameter $(17.4 \mathrm{~cm})$ were obtained from $15 \mathrm{~kg} \mathrm{da}^{-1}$ treatment of Isera (early) cultivar; the highest oil content $(45.2 \%)$, oil yield $\left(132.0 \mathrm{~kg} \mathrm{da}^{-1}\right)$ and plant height $(147.7 \mathrm{~cm})$ were respectively observed in $3 \mathrm{~kg} \mathrm{da}^{-1}$ treatment of C-70165 (medium early), Isera and Teknosol (late) cultivars; the highest protein content $(27.2 \%)$ was observed in $12 \mathrm{~kg} \mathrm{da}^{-1}$ nitrogen treatment of Teknosol cultivar; the highest harvest index (38.5\%) was obtained from $9 \mathrm{~kg} \mathrm{da}^{-1}$ nitrogen treatment of Isera cultivar. While the effects of nitrogen doses on oil content were irregular, nitrogen doses had positive effects on seed yield.
\end{abstract}

Keywords: Nitrogen, Harvest index, Helianthus annuus, Protein content, Seed yield, Oil content

\section{INTRODUCTION}

Sunflower (Helianthus annuus L.) with relatively high adaptation capacity, availability for machinery agriculture, low labor need and high oil content has a widespread production potential throughout the world (Mohammad and Mosavi Johromi, 2011; Namwar et al., 2012). Sunflower seed oil is highly rich in unsaturated fatty acids [oleic acid (20\%) and linoleic acid (70\%)] required for cell structure. It is also light colored, delicious and easily digested. Sunflower oil catalyzes the intake of oil-soluble vitamins ( $\mathrm{A}, \mathrm{D}, \mathrm{E}$ and $\mathrm{K}$ ) in to body and plays a remedial role in cardiovascular and cholesterol diseases (Kolsarici et al., 2005).

Sunflower oil consumption has recently been increasing in Turkey. Despite such increases in consumptions, yields have not reached to desired levels because of low soil fertility levels, high production costs and insufficient or improper technology utilization in production activities (Semerci and Meral, 2001). Even with sufficient and proper technologies, desired or optimum yield levels are not able to be reached because of insufficient soil fertility levels. Researchers mostly focus on cultural practices and external plant nutrient treatments to improve soil fertility. Fertilizers containing essential plant nutrients may significantly improve yield levels and quality traits of sunflower (Sadras, 2006).
Nitrogen $(\mathrm{N})$ is the most significant nutrient to improve yield and quality of sunflower seeds. It is an essential plant nutrient to stimulate plant growth and development and ultimately yield and quality (Ullah et al., 2010). Fertilizer needs of common sunflower cultivars vary based on ecological conditions annul precipitations, irrigation regimes and plant species. Higher nitrogen doses improve photosynthesis process, increase leaf area and net digestion rates (Munir et al., 2007). However, excessive nitrogen treatments may result in environmental pollution, imbalanced plant nutrition, decreased quality and increased production cost (Gok et al., 2006). Therefore, proper nitrogen doses should be so selected as to improve yield and quality but to prevent negative impacts on human and soil health.

Nitrogenous fertilizers have highly significant impacts on vegetative and generative development periods of cultural crops. Such impacts vary greatly based on species, treatment doses and growing sites. Therefore, ecological conditions, species and nitrogen doses should be taken into consideration in researches. The objective of the present study was to determine the effect of nitrogen doses $\left(0,3,6,9,12\right.$ and $\left.15 \mathrm{~N} \mathrm{~kg} \mathrm{da}^{-1}\right)$ on yield and quality traits of common sunflower (Helianthus annuиs L.) cultivars (Isera, C-70165 and Teknosol) with different growth periods. 


\section{MATERIALS AND METHODS}

The Research Center of the Atatürk University in Erzurum-Turkey with an altitude of $1782 \mathrm{~m}$ is located between $39^{\circ} 56^{\prime} 06.69^{\prime \prime}$ North latitudes and 41 $14^{\prime} 00.80^{\prime \prime}$ East longitudes. Precipitation, temperature and relative humidity data were supplied from the meteorological station located $2 \mathrm{~km}$ north of the research center and these data are provided in Table 1.
Soil characteristics of the experimental fields were determined by taking soil samples form $0-20 \mathrm{~cm}$ soil layer and analyzing them at laboratories of Soil Science and Plant Nutrition Department of Ataturk University Agricultural Faculty. Experimental soils were slightly alkaline ( $\mathrm{pH} 7.73$ and 7.54) with clay-loam texture. Compared to analyses results of Kacar (2009), experimental soils of the years 2011-2012 had low lime contents $(0.68 \%$ and $0.20 \%)$, moderate organic matter contents $(2.23 \%$ and $2.63 \%)$, sufficient available phosphorus (110.9 and $130.9 \mathrm{~kg} \mathrm{ha}^{-1}$ ) and potassium (1548 and $1098 \mathrm{~kg} \mathrm{ha}^{-1}$ ) levels.

Table 1. Precipitation, temperature and relative humidity during the field trial run in 2011 and 2012

\begin{tabular}{lcccccc}
\hline \multirow{2}{*}{ Months } & \multicolumn{2}{c}{$\begin{array}{c}\text { Mean precipitation } \\
(\mathbf{m m})\end{array}$} & \multicolumn{2}{c}{$\begin{array}{c}\text { Mean temperature } \\
\left({ }^{\circ} \mathbf{C}\right)\end{array}$} & \multicolumn{2}{c}{ Mean relative humidity $(\%)$} \\
\cline { 2 - 7 } & $\mathbf{2 0 1 1}$ & $\mathbf{2 0 1 2}$ & $\mathbf{2 0 1 1}$ & $\mathbf{2 0 1 2}$ & $\mathbf{2 0 1 1}$ & $\mathbf{2 0 1 2}$ \\
\hline May & 105.2 & 73.0 & 9.6 & 11.4 & 69.5 & 68.0 \\
June & 55.3 & 7.0 & 14.6 & 15.7 & 63.4 & 83.6 \\
July & 26.6 & 19.8 & 19.6 & 19.0 & 53.3 & 52.3 \\
August & 21.8 & 22.8 & 19.4 & 20.0 & 48.2 & 49.6 \\
September & 7.5 & 11.0 & 13.9 & 15.0 & 53.8 & 48.4 \\
Total/Average & 216.4 & 133.6 & 15.4 & 16.2 & 57.6 & 60.4 \\
\hline
\end{tabular}

Isera (early), C-70165 (medium-early) and Teknosol (late) common sunflower cultivars were used as the plant material of experiments. Specified nitrogen doses $(0,3,6$, 9,12 and $15 \mathrm{~kg} \mathrm{~N} \mathrm{da}^{-1}$ ) and $6 \mathrm{~kg} \mathrm{da}^{-1}$ phosphorus fertilizer were applied during the sowing.

\section{Experimental design and measurements}

Field experiments were carried out in the Randomized Complete Block Design with three replications. Each plot was $4 \mathrm{~m}$ long and $2.8 \mathrm{~m}$ wide with 4 rows. Row spacing was $70 \mathrm{~cm}$ and on-row plant spacing was $25 \mathrm{~cm}$. The $21 \%$ ammonium sulphate was used as the nitrogenous fertilizer and $45 \%$ triple super phosphate was used as phosphorus fertilizer. Sowing was performed on $2^{\text {nd }}$ of May in 2011 and $11^{\text {th }}$ of May in 2012. Sowing was performed manually and 3 seeds were sown in each sowing bed. Thinning was performed 2-3 weeks after emergence and only one seedling was left in each bed. Hoeing was performed throughout the growing season for weed control. Plants were irrigated twice with furrow irrigation during head formation and flowering periods. Plants were harvested when lower leaves, the sterile leaves around the head and fertile leaves within the head dried out and defoliated bract leaves turned into yellow or brown and all the seeds of head ripened. Side rows and a seed bed at corners were omitted as to consider side effects and 20 plants were harvested manually from central 2 rows. Harvest was performed 18-28 September of 2011 and 10-18 September of 2012. Among the investigated traits, plant height (the section from the soil surface to shoot-head connection part) and head diameter were measured over 20 plant samples at physiological maturation stage and average of measurements were taken. Dried seed samples were taken from each plot in three replications and $4 \times 100$ seeds were counted and weighed to determine thousand-seed weight. Then, seeds were hulled and kernel ratios were determined. Seed yield was calculated for each decare by using the yields of each plot. Oil contents were determined from two gram samples from each plot in a soxhlet extractor with anhydrous ether for six hours. Oil yield was calculated as "Oil yield $=$ oil content $\mathrm{x}$ seed yield $/ 100 "$ " Nitrogen contents were determined from 0.2 gram samples of each plot by using Kjeldahl method. These ratios were multiplied with 6.25 to get protein contents. Harvest index was calculated by "Harvest Index $=$ seed yield $\mathrm{x}$ plat weight $/ 100$ ".

\section{Data analysis}

Statistical data analyses were performed by using SPSS software. Differences among treatment means were compared by Duncan's multiple range test at $\mathrm{p}<0.05$ level (Steel and Torrie, 1980).

\section{RESULTS AND DISCUSSION}

\section{Plant height}

With regard to effects of different nitrogen doses on plant height of three sunflower cultivars, only the year, cultivar and year $\mathrm{x}$ cultivar interactions were found to be significant $(\mathrm{p}<0.01)$. Mean plant height observed in the year $2011(151.3 \mathrm{~cm})$ was higher than the plant height observed in the year $2012(138.4 \mathrm{~cm})$. Such a difference may be resulted from climate, environmental conditions and cultural practices. Sufficient precipitation, temperature rises, lighting intensity, daylight duration, latitude and longer photo periods during the growing seasons may increase plant heights (Kaya, 1998). Montemurro et al. (2007) indicated that high precipitations improved early vegetative development of sunflower and environmental conditions had positive 
impacts on plant growth and development. Considering the average of years, it was observed that plant height of the late cultivar (Teknosol; $173.9 \mathrm{~cm}$ ) was greater than the plant heights of early cultivar (Isera; $127.8 \mathrm{~cm}$ ) and medium-early cultivar (C-70165; $132.9 \mathrm{~cm}$ ) (Table 2).
Plant genetics might have been effective in having different plant heights in different cultivars. Plant height values of the present study comply with the findings of Ozer et al. (2004) and Ergen and Saglam (2005).

Table 2. The means of the agronomical and quality characteristics of sunflower cultivars grown in Erzurum, 2011 and 2012

\begin{tabular}{|c|c|c|c|c|c|c|c|c|c|c|}
\hline \multicolumn{2}{|c|}{ Treatments } & $\begin{array}{c}\text { PH } \\
(\mathrm{cm})\end{array}$ & $\begin{array}{l}\mathrm{HD} \\
(\mathrm{cm})\end{array}$ & $\begin{array}{l}\mathbf{K R} \\
(\%) \\
\end{array}$ & $\begin{array}{c}\text { SY } \\
\left(\mathrm{kg} \mathrm{da}^{-1}\right)\end{array}$ & $\begin{array}{c}\text { TSW } \\
(\mathrm{g})\end{array}$ & $\begin{array}{c}\mathrm{OY} \\
\left(\mathrm{kg} \mathrm{da}^{-1}\right)\end{array}$ & $\begin{array}{l}\mathrm{OC} \\
(\%)\end{array}$ & $\begin{array}{l}\mathrm{PC} \\
(\%)\end{array}$ & $\begin{array}{c}\text { HI } \\
(\%)\end{array}$ \\
\hline \multirow{2}{*}{ Year $(Y)$} & 2011 & $151.3 \mathrm{a}$ & $17.9 \mathrm{a}$ & $71.2 \mathrm{a}$ & $352.3 \mathrm{a}$ & $66.3 \mathrm{a}$ & $142.7 \mathrm{a}$ & $40.4 \mathrm{a}$ & $25.5 \mathrm{~b}$ & $39.9 \mathrm{a}$ \\
\hline & 2012 & $138.4 \mathrm{~b}$ & $16.3 \mathrm{~b}$ & $72.5 \mathrm{~b}$ & $296.7 \mathrm{~b}$ & $59.6 \mathrm{~b}$ & $113.5 \mathrm{~b}$ & $38.1 \mathrm{~b}$ & $26.7 \mathrm{a}$ & $36.4 \mathrm{~b}$ \\
\hline \multirow{3}{*}{$\begin{array}{l}\text { Cultivar } \\
\text { (C) }\end{array}$} & Isera & $127.8 \mathrm{c}$ & $17.6 \mathrm{a}$ & $71.3 \mathrm{~b}$ & $350.7 \mathrm{a}$ & $69.6 \mathrm{a}$ & $141.5 \mathrm{a}$ & $40.3 \mathrm{~b}$ & $25.4 \mathrm{~b}$ & $44.1 \mathrm{a}$ \\
\hline & C-70165 & $132.9 \mathrm{~b}$ & $16.4 \mathrm{~b}$ & $75.7 \mathrm{a}$ & $313.3 \mathrm{~b}$ & $60.5 \mathrm{~b}$ & $136.7 \mathrm{~b}$ & $43.4 \mathrm{a}$ & $25.0 \mathrm{c}$ & $41.4 \mathrm{~b}$ \\
\hline & Teknosol & $173.9 \mathrm{a}$ & $17.3 \mathrm{a}$ & $68.5 \mathrm{~b}$ & $309.5 \mathrm{~b}$ & $58.7 \mathrm{c}$ & $106.1 \mathrm{c}$ & $34.1 \mathrm{c}$ & $27.9 \mathrm{a}$ & $29.0 \mathrm{c}$ \\
\hline \multirow{6}{*}{$\begin{array}{l}\text { Nitrogen } \\
\text { Dose (A) }\end{array}$} & $\mathbf{0}$ & 146.6 & 17.3 & $72.7 \mathrm{a}$ & $327.4 \mathrm{bc}$ & $63.9 \mathrm{~b}$ & $128.4 \mathrm{ab}$ & $39.3 \mathrm{bc}$ & $26.5 \mathrm{~b}$ & 38.1 \\
\hline & 3 & 147.7 & 17.1 & $71.6 \mathrm{~b}$ & $325.9 \mathrm{bc}$ & $62.6 \mathrm{c}$ & $132.0 \mathrm{a}$ & $40.3 \mathrm{a}$ & $23.5 \mathrm{~d}$ & 38.4 \\
\hline & 6 & 144.3 & 16.9 & $71.7 \mathrm{~b}$ & $305.3 \mathrm{~d}$ & $62.2 \mathrm{~cd}$ & $120.4 \mathrm{c}$ & $38.9 \mathrm{c}$ & $26.9 \mathrm{ab}$ & 38.2 \\
\hline & 9 & 145.8 & 16.7 & $71.5 \mathrm{~b}$ & $315.9 \mathrm{~cd}$ & $61.6 \mathrm{~d}$ & $126.4 b$ & $39.8 \mathrm{ab}$ & $25.9 \mathrm{c}$ & 38.5 \\
\hline & 12 & 142.2 & 17.3 & $71.7 \mathrm{~b}$ & $331.4 \mathrm{ab}$ & $62.2 \mathrm{~cd}$ & $130.3 \mathrm{ab}$ & $39.2 \mathrm{bc}$ & $27.2 \mathrm{a}$ & 37.9 \\
\hline & 15 & 142.7 & 17.4 & $71.8 \mathrm{~b}$ & $341.1 \mathrm{a}$ & $65.2 \mathrm{a}$ & $130.9 \mathrm{ab}$ & $38.1 \mathrm{~d}$ & $26.7 \mathrm{ab}$ & 37.8 \\
\hline $\mathrm{CV}(\%)$ & & 16.40 & 9.12 & 4.54 & 15.82 & 10.82 & 21.71 & 11.41 & 10.35 & 19.06 \\
\hline \multicolumn{2}{|c|}{$\begin{array}{l}\text { Variances and their } \\
\text { significance }\end{array}$} & $\begin{array}{c}\text { PH } \\
(\mathbf{c m})\end{array}$ & $\begin{array}{l}\text { HD } \\
(\mathrm{cm})\end{array}$ & $\begin{array}{l}\text { KR } \\
(\%)\end{array}$ & $\begin{array}{c}\text { SY } \\
\left(\mathrm{kg} \mathrm{da}^{-1}\right)\end{array}$ & $\begin{array}{c}\text { TSW } \\
\text { (g) }\end{array}$ & $\begin{array}{r}\text { OY } \\
(\mathbf{k g} \\
\left.\mathbf{d a}^{-1}\right)\end{array}$ & $\begin{array}{l}\text { OC } \\
(\%)\end{array}$ & $\begin{array}{l}\text { PC } \\
(\%)\end{array}$ & $\begin{array}{c}\text { HI } \\
(\%)\end{array}$ \\
\hline \multicolumn{2}{|c|}{ Year } & $* *$ & $* *$ & $* *$ & $* *$ & $* *$ & $* *$ & $* *$ & $* *$ & *** \\
\hline \multicolumn{2}{|c|}{ Cultivar } & $* *$ & $* *$ & $* *$ & $* *$ & $* *$ & $* *$ & $* *$ & $* *$ & $* *$ \\
\hline \multicolumn{2}{|c|}{ Nitrogen } & ns & ns & $* *$ & $* *$ & $* *$ & $* *$ & $* *$ & $* *$ & ns \\
\hline \multicolumn{2}{|c|}{ Year x Cultivar } & $* *$ & $*$ & $*$ & $* *$ & $* *$ & $* *$ & ns & $* *$ & $* *$ \\
\hline \multicolumn{2}{|c|}{ Year $x$ Nitrogen } & ns & ns & $* *$ & $* *$ & $* *$ & $* *$ & $* *$ & $* *$ & $* *$ \\
\hline \multicolumn{2}{|c|}{ Cultivar $x$ Nitrogen } & ns & ns & $* *$ & $* *$ & $* *$ & $* *$ & $* *$ & $* *$ & $* *$ \\
\hline \multicolumn{2}{|c|}{ Year $x$ Cultivar $x$ Nitroge } & ns & $\mathrm{ns}$ & $*$ & $* *$ & $* *$ & $* *$ & $* *$ & $* *$ & $* *$ \\
\hline
\end{tabular}

$*$, ** Significant F-value at the $\mathrm{p}<0.05$ and $\mathrm{p}<0.01$ level, respectively. ns, nonsignificant F-value. For each main effect, the difference between mean values shown on the same column with the same letter is not significant according to Duncan's Multiple Range test at $P<0.05$. CV, coefficient of variation. PH: Plant height (cm), HD: Head diameter (cm), KR: Kernel ratio (\%), SY: Seed yield (kgda $\left.{ }^{-1}\right)$, TSW: 1000 seed weight (g), OY: Oil yield $\left(\mathrm{kgda}^{-1}\right)$, OC: Oil content (\%), PO: Protein content (\%), HI: Harvest index (\%)

\section{Head diameter}

Considering the effects of different nitrogen doses on head diameters, year, cultivar $(\mathrm{p}<0.01)$ and year $\mathrm{x}$ cultivar interactions $(\mathrm{p}<0.05)$ were found to be significant and the other traits were not significant (Table 2). The mean head diameter was $17.9 \mathrm{~cm}$ in 2011 and $16.3 \mathrm{~cm}$ in 2012. The difference between the head diameters of the years was because of climate conditions (Table 1). With regard to average of years, head diameter of early, medium-early and late cultivar ( Isera, C-70165 and Teknosol ) was respectively observed to be $17.6,16.4$ and $17.3 \mathrm{~cm}$. Cosge and Bayraktar (2004) indicated head diameter as the most significant yield parameter and reported significant effects of head diameter on seed yield, number of seeds, thousand seed weight and oil yield. However, Kaya et al. (2009) indicated yield increases until a head diameter of $24 \mathrm{~cm}$ but reported decreased oil contents and falling seeds and thus decreased yields because of larger seed sizes for head diameters over $24 \mathrm{~cm}$. In another study carried about head diameters, Karaaslan et al. (1999) reported similar head diameters (between 17.23-19.76 cm) with this study. 


\section{Kernel ratio}

Kernel ratio was $71.2 \%$ in the first year and $72.5 \%$ in the second year of the experiments. The difference between the years was found to be significant $(p<0.01)$. Different climate parameters may have resulted in different photosynthesis rates and thus different seed hull and kernel ratios (Ahmad, 2001). Significant differences were also observed in kernel ratios of the cultivars $(p<0.01)$. Considering the average of years, the highest kernel ratio was obtained from medium-early C-70165 cultivar $(75.7 \%)$ and the lowest value was observed in late Teknosol cultivar $(68.5 \%)$ (Table 2). The differences were because of genetics of the cultivars. The present findings comply with the results of Karaaslan et al. (1999) and Karaaslan et al. (2007). The differences in kernel ratios of different nitrogen doses were found to be significant at $\mathrm{p}<0.01$ level. As an average of the years, kernel ratios of $0,3,6,9,12$ and $15 \mathrm{~kg}$ nitrogen treatments were respectively observed as 71.5, 70.8, 71.2, 70.9, 71.1 and $71.8 \%$ (Table 1 and 2).

\section{Seed yield}

With regard to seed yields of common sunflower cultivars with different growth periods under different nitrogen doses, year, cultivar, nitrogen doses and other treatments were all found to be significant $(\mathrm{p}<0.01)$ (Figure 1, Table 2).

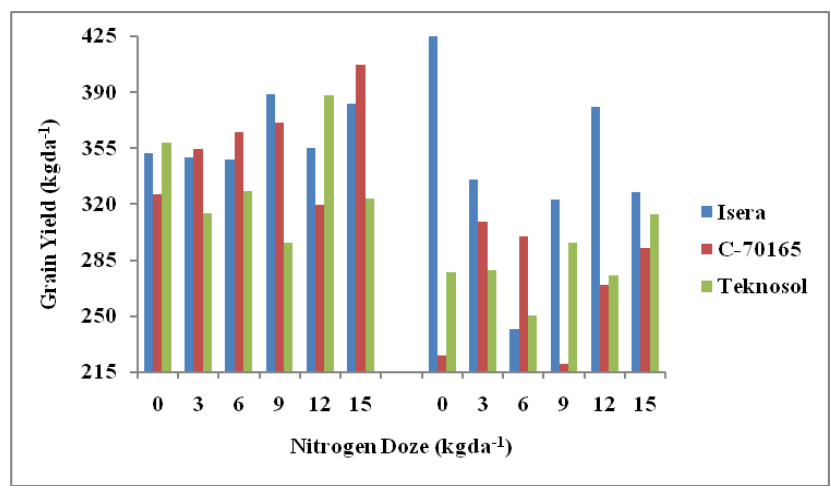

Figure 1. Seed yields $\left(\mathrm{kg} \mathrm{da}^{-1}\right)$ of sunflower cultivars under different nitrogen doses in 2011 and 2012.

Seed yield decar-1 was $55.6 \mathrm{~kg}$ higher in 2011 (352.3 $\mathrm{kg}$ ) than the seed yield of $2012(296.7 \mathrm{~kg})$. Higher precipitations and available phosphorus levels of the first year resulted in higher seed yields in 2011. Sunflower seed yield vary generally based on cultivars and environmental conditions (Killi, 1997). Also, Evci et al. (2006) indicated that decreasing soil moistures may result in significant decreases in sunflower seed yields. Water stress especially during the flowering or vegetative growth periods may significantly reduce seed yields (Kadayifci and Yildirim, 2000). Considering the average of years, seed yield per decare of late Isera cultivar $(350.7 \mathrm{~kg})$ was higher than the seed yield of medium-early C-70165 $(313.3 \mathrm{~kg})$ and late Teknosol cultivar $(309.5 \mathrm{~kg})$. Again the differences between seed yields of the cultivars were mainly because of cultivar genetics. Current findings comply with the results of Ergen and Saglam (2005) and
Smiderle et al. (2007). Seed yields of 0, 3, 6, 9, 12 and 15 $\mathrm{kg}$ nitrogen treatments were respectively observed as $327.4,325.9,305.3,315.9,331.4$ and $341.1 \mathrm{~kg}$. The highest seed yield was observed in $15 \mathrm{~kg}$ nitrogen treatment $(341.1 \mathrm{~kg})$. Thusly in previous studies, Ozer et al. (2004) reported significant effects of nitrogenous fertilizers on seed yield and quality and Ali et al. (2012) and Nasim et al. (2012) reported increasing sunflower yield levels with increasing nitrogen doses. Thavaprakash (2004) and Namvar et al. (2012) observed the highest seed yield levels at $12 \mathrm{~kg}$ nitrogen dose and Evci et al. (2006) reported the highest yield at nitrogen doses of between 5$10 \mathrm{~kg}$. Current findings also comply with the results of those previous studies.

\section{Thousand seed weight}

With regard to thousand seed weight, year, cultivar, nitrogen, year $\mathrm{x}$ cultivar, year $\mathrm{x}$ nitrogen, cultivar $\mathrm{x}$ nitrogen and year $\mathrm{x}$ cultivar $\mathrm{x}$ nitrogen interactions were found to be significant $(\mathrm{p}<0.01)$ (Table 2). Thousand seed weight of the year 2011 (66.3 g) was $6.7 \mathrm{~g}$ higher than the thousand seed weight of the year 2012 (59.6 g). Lower thousand seed weight of the second year was because of lower precipitation and higher temperature of the second year (Table 1). With regard to average of year, the greatest thousand seed weight was obtained from early Isera cultivar $(69.6 \mathrm{~g})$ and the lowest value was seen in late Teknosol cultivar $(58.7 \mathrm{~g})$. Genetics of the cultivars were effective in differences in thousand seed weights of the cultivars. Current findings were parallel to the results of Karaaslan et al. (2007). Again as the average of years, the highest thousand seed weight was observed in $15 \mathrm{~kg}$ nitrogen dose $(65.2 \mathrm{~g})$. The thousand seed weights of 0,3 , 6,9 and $12 \mathrm{~kg}$ nitrogen doses were respectively observed as $63.9,62.6,62.2,61.6$ and $62.2 \mathrm{~g}$. increasing thousand seed weights were also reported with increasing nitrogen doses (Nasim et al., 2012). Also, Al-Thabet (2006) and Namvar et al. (2012) reported similar thousand seed weights with the present study.

\section{Oil yield}

With regard to effects of nitrogen doses on oil yield of common sunflower cultivars, all traits were found to be significant $(\mathrm{p}<0.01)$ (Table 2). The oil yield was $142.7 \mathrm{~kg}$ in 2011 and $113.5 \mathrm{~kg}$ in 2012. Higher oil yield of the first year was because of higher seed yield $(352.3 \mathrm{~kg})$ and oil ratio $(40.4 \%)$ of the first year than the second year $(296.7$ $\mathrm{kg}$ and $38.1 \%$ ). Considering hte average of years, oil yield per decare of common sunflower cultivars of early Isera, medium-early C-70165 and late Teknosol was respectively observed as $141.5,136.7$ and $106.1 \mathrm{~kg}$. Seed yield and oil content have positive impacts on oil yields (Cosge and Bayraktar, 2004). A previous study revealed significant decrease in oil yield when the thousand seed weight was over $70 \mathrm{~g}$, oil content was over $53 \%$ and head diameter was over $24 \mathrm{~cm}$ (Kaya et al., 2009). In previous studies carried out in different regions and with different cultivars, Tuncturk et al. (2005) reported oil yield as 52.1 $\mathrm{kg} \mathrm{da}^{-1}$ and Dogan (2010) reported oil yields as between $10.70-32.28 \mathrm{~kg} \mathrm{da}^{-1}$. Our findings were lower than the 
results of those previous studies and similar to findings of Kaya et al. (2009). Such differences were mainly due to differences in cultivars, environmental and climate conditions. Again as the average of years, oil yield of 0,3 , $6,9,12$ and $15 \mathrm{~kg}$ nitrogen doses were respectively observed as 128.4, 132.0, 120.4, 126.4, 130.3 and 130.9 $\mathrm{kg}$. Al-Thabet (2006) indicated that nitrogen rates are always related to oil yield in every part of the world where sunflower is cultivated. While Foroud and Bohrani (2000) indicated significantly increasing seed and oil yields and head diameters with increasing nitrogen doses, Hussain et al. (2011) reported significantly decreasing oil yield with increasing nitrogen doses.

\section{Oil content}

According to variance analysis of oil content, while year, cultivar, nitrogen, year $\mathrm{x}$ nitrogen, cultivar $\mathrm{x}$ nitrogen and year $\mathrm{x}$ cultivar $\mathrm{x}$ nitrogen interactons were found to be significant $(\mathrm{p}<0.01)$, year $\mathrm{x}$ cultivar interaction was found to be insignificant (Figure 2, Table $2)$.



Figure 2. Oil contents (\%) of sunflower cultivars under different nitrogen doses in 2011 and 2012.

Oil content was determined to be $40.4 \%$ in the first year and $38.1 \%$ in the second year of the experiments. Differences between the oil contents of the years might be due to higher precipitations, temperatures, available potassium and lime levels and lower organic matter contents of the first year than the second year (Table 1). Although sunflower is resistant against environmental conditions (temperature and precipitation), climate factors play a significant role in yield and yield traits. Researchers indicated environmental factors as the most significant factors affecting the oil quality of sunflower (Karaaslan et al., 2007). Especially during the periods with insufficient precipitation, excessive water loss result in weak seeds, increased hull ratio and decreased oil content (Kaya et al., 2009). With regard to average years, oil content of medium-early C-70165 cultivar (43.4\%) was higher than the oil content of early Isera $(40.3 \%)$ and late Teknosol cultivar $(34.1 \%)$. In previous studies, oil content of sunflower cultivars was reported as $41.46 \%$ by Thavaprakash (2004), as $41.3 \%$ by Tuncturk et al. (2005), as between $39.1-45.9 \%$ by Karaaslan et al. (2007) and as between $38.0-53.4 \%$ by Kaya et al. (2009). Current findings comply with the results of those earlier studies.
Oil content of $0,3,6,9,12$ and $15 \mathrm{~kg}$ nitrogen doses were respectively observed as $39.3 \%, 40.3 \%, 38.9 \%, 39.8 \%$ and $39.2 \%$. The lowest oil content was obtained from 15 $\mathrm{kg}$ nitrogen treatment $(38.1 \%)$ and the highest oil content was obtained from $3 \mathrm{~kg}$ nitrogen treatment (40.3\%). Although the lowest oil content was obtained from the highest nitrogen treatment, oil content respond to decreasing nitrogen doses was irregular. Previous researches also indicated significant decreases in oil content with increasing nitrogen treatments (Osman and Awed, 2010). Bakht et al. (2010) and Hussain et al. (2011) observed the lowest oil content in control treatments without any nitrogen applications. Current findings were similar to results reported by Osman and Awed (2010).

\section{Protein content}

For protein content of nitrogen treatments, year, cultivar, nitrogen, year x cultivar, year x nitrogen, cultivar $\mathrm{x}$ nitrogen and year $\mathrm{x}$ cultivar $\mathrm{x}$ nitrogen interactions were found to be significant $(\mathrm{p}<0.01)$ (Table 2). As the average of experimental factors, protein content of the year 2011 $(25.5 \%)$ was lower than the protein content of 2012 (26.7\%). Lower protein contents of 2012 were because of lower precipitation of the second year than the first year (133.6 mm) and higher temperatures of the second year (Table 1 and 2). Tomar et al. (1996) reported decreased protein contents in excessively moist soils and the highest protein contents in dry soils. With regard to protein contents of the cultivars, the greatest value was observed in late Teknosol $(27.9 \%)$ and the lowest value was seen in medium-early C-70165 cultivar $(25.0 \%)$. Again such differences in protein contents of the cultivars were because of the genetics of the cultivars. Previous researchers reported the protein contents of sunflower cultivars as between 16.0-25.0\% (Ayub et al., 1998; Karaaslan et al., 1999). These findings were similar to results of the present study. Protein content of $0,3,6,9$, 12 and $15 \mathrm{~kg}$ nitrogen treatments were respectively observed as 26.5, 23.5, 26.9, 25.9, 27.2 and $26.7 \%$. Tripathi and Sawhney (1992) indicated that nitrogen treatments improved protein contents of sunflower seeds. Iqbal et al. (2008) obtained the highest protein content from $15 \mathrm{~kg}$ nitrogen treatment.

\section{Harvest index}

For harvest index, year, cultivar, year x cultivar, year $\mathrm{x}$ nitrogen, cultivar $\mathrm{x}$ nitrogen and year $\mathrm{x}$ cultivar $\mathrm{x}$ nitrogen interactions were found to be significant $(\mathrm{p}<0.01)$, but nitrogen doses were not found to be significant (Table 2). Harvest index of the years 2011 and 2012 were respectively observed as $39.9 \%$ and $36.4 \%$. Harvest index of the year 2011 was higher than the harvest index of 2012. Since the harvest index was obtained as the ratio of seed yield to plant weight, there is a positive relationship between harvest index and seed yield. Since climate and environmental factors influence seed yield, these factors are also effective on harvest index (Table 1). Mojaddam et al. (2011) reported significant decreases in seed yield and consequently in harvest index under excessive drought stress conditions. Compared to generative growth, 
excessive drought stress also decreases the productivity and thus decrease the harvest index (Pandey et al., 2000). Considering the average of years, the greatest and the lowest harvest index values were respectively observed in early Isera $(44.1 \%)$ and late Teknosol cultivar $(29.0 \%)$. Such differences in harvest index values were because of genetics of the cultivars.

\section{CONCLUSION}

Differences in climate and environmental factors of the experimental years significantly affected the investigated traits. While plant height, head diameter, thousand seed weight, oil content, seed yield, oil yield and harvest index of the first year were higher than the values of the second year, kernel ratio and protein content of the second year were higher than the values of the first year. Significant differences were observed in investigated traits of cultivars. Considering the yield and quality traits, plant height and protein content of late Teknosol, head diameter, thousand seed weight, seed yield, oil yield and harvest index of early Isera and kernel ratio and oil content of medium-early C-70165 cultivar were higher than the others. Nitrogen doses had significant effects on investigated traits. The highest plant height $(147.7 \mathrm{~cm})$, oil content $(40.3 \%)$ and oil yield (132.0 $\left.\mathrm{kg} \mathrm{da}^{-1}\right)$ were observed in $3 \mathrm{~kg} \mathrm{da}^{-1}$ nitrogen treatment, the highest harvest index $(38.3 \%)$ was observed in $9 \mathrm{~kg} \mathrm{da}^{-1}$ nitrogen treatment, the highest protein content $(27.2 \%)$ was observed in $12 \mathrm{~kg} \mathrm{da}^{-1}$ nitrogen treatment, the highest thousand seed weight $(65.2 \mathrm{~g})$ and seed yield $(341.1 \mathrm{~kg} \mathrm{da}$ $\left.{ }^{1}\right)$ were observed in $15 \mathrm{~kg} \mathrm{da}^{-1}$ nitrogen treatment.

In conclusion, control treatment $\left(0 \mathrm{~kg} \mathrm{da}^{-1}\right)$ of Isera (early) cultivar provided the most satisfactory seed and oil yields, $12 \mathrm{~kg} \mathrm{da}^{-1}$ treatment yielded the best results for Teknosol (late) cultivar, $15 \mathrm{~kg} \mathrm{da}^{-1}$ treatment had the best seed yield and $6 \mathrm{~kg} \mathrm{da}^{-1}$ nitrogen treatment had the most satisfactory oil yield for C-70165 cultivar (medium-early). Considering the seed yields of the cultivars and nitrogen treatments, the cultivars Isera and C-70165 and $15 \mathrm{~kg} \mathrm{da}^{-1}$ nitrogen treatment can be recommended for seed yield, 3 $\mathrm{kg} \mathrm{da}^{-1}$ for oil yield.

\section{ACKNOWLEDGEMENTS}

Acknowledgements are extended to Assoc. Prof. Dr. Zeki GÖKALP for the technical supports given during the preparation of this paper.

\section{LITERATURE CITED}

Ahmad, S. 2001. Environmental effect on seed characteristics of sunflower (Helianthus annuus L.). journal of Agronomy and Crops Science, 187: 213-216.

Ali, A., A. Ahmad, T. Khaliq and J. Akhtar. 2012. Phenology and yield of sunflower (Helianthus annuus L.) hybrids as affected by varying plant spacing and nitrogen levels under semiarid conditions of sargodha, punjab. Pakistan Journal of Science, 64(2): 98-105.

Al-Thabet, S.S. 2006. Effect of plant spacing and nitrogen levels on growth and yield of sunflower (Helianthus annus L.). J. King Saud University, Agricultural Sciences, 19(1): 1-11.

Bakht, J., M. Shafi, M. Yousaf and H.U. Shah. 2010. Physiology, phenology and yield of sunflower (autumn) as effected by npk fertilizer and hybrids. Pakistan Journal of Bot., 42(3): 1909-1922.

Cosge, B. and N. Bayraktar. 2004. Correlations between some yield and yield components in sunflower (Helianthus annuus L.) hybrid, line and varieties. Journal of agricultural science, 10(1): 111-115.

Dogan, M. 2010. A Research about definıng technologic and agricultural properties of sun seed species under non 1rrigable conditions. Master Thesis, Cukurova University, Institute of Science and Technology, Adana.

Ergen, Y. and C. Saglam. 2005. Yield and yield characters of differrent confectionery sunflower varieties in conditions of Tekirdag. Journal of Tekirdag Agricultural Faculty, 2(3): 221-227.

Evci G., Y. Kaya, V. Pekcan, S. Durak and T. Kahraman. 2006. The Determination of The Effect of Cover Crop Before Sunflower Production on Seed Yield, the Application of Nitrogen Rate and Water Content in the Soil in Trakya Region. Trakya Univ J Sci, 7(1): 71-75

Foroud, S. and M.J. Bohrani. 2000. Sunflower summer-planting yield as affected by plant population and nitrogen application rates. Iran Agricultural Research, 19(1): 63-72.

Gok, M., K. Dogan and A. Coskan. 2006. Effects of Divers Organic Substrat Application on Denitrification and Soil Respiration under Different Plant Vegetation in Çukurova Region. International Symposium on Water and Land Management for Sustainable Irrigated Agriculture. April 4-8, 2006, Adana-Turkey

Hussain, S.S., F.A. Misger, A. Kumar and M.H. Baba. 2011. Response of nitrogen and sulphur on biological and economic yield of sunflower (Helianthus annuus L.). Research Journal of Agricultural Sciences, 2(2): 308-310.

Iqbal, J., B. Hussain, M.F. Saleem, M.A. Munir and M. Aslam. 2008. Bio-economics of autumn planted sunflower (Helianthus annuus L.) hybrids under different npk application. Pakistan Journal of Agricultural Science, 45(3): 19-24.

Kacar, B. 2009. Soil Analysis (Second Edition). Nobel Publication No. 1387, Ankara. (in Turkish)

Kadayifci A. and O. Yildirim. 2000. The response of sunflower grain yield to water. Turk. J. Agric. For., 24: 137-145.

Karaaslan, D., T. Sogut and D. Sakar. 1999. Determination of suitable sunflower varieties to $2^{\text {nd }}$ crop agricultural in irrigated of Diyarbakır conditions. Turkish Field Crops Congress, 15-18 November, 1999, pp. 52-56, Adana, Turkey (in Turkish).

Karaaslan, D., Ö. Toncer and T. Sogut. 2007. Evaluation with regard to yield and some yield components of some sunflower varieties (Helianthus annuusL.) in Southeastern Anatolia Region Conditions.Journal of Agricultural Faculty of Harran University, 11(1/2): 31-38 (in Turkish).

Kaya, Y. 1998. Genotype and Environment İnteractions with Physiological Maturity of Sunflower (Helianthus annuus L.) Hybrids in Western Nebraska. MS Thesis, University of Nebraska, Lincoin, NE. USA.

Kaya, Y., G. Evci, V. Pekcan, T. Gucer and M.İ. Yilmaz. 2009. The determination relationships between oil yield and some yield traits in sunflower. Ankara University Faculty of Agriculture, Journal of Agricultural Sciences, 15(4): 310318.

Killi, F., 1997. A research on yield and yield components of some hybrid oil sunflower varieties (Helianthus annuus L.) under ecological conditions of Kahramanmaras. Trop. J. Agri. Fore., 21: 149-55

Kolsarici, O., A. Gür, D. Basalma, M.D. Kaya and N. Isler. 2005. Production of oily plants. TMMOB Board of Agricultural Engineering, Turkey Agriculture Engineering 
VI. Technical Congress Proceedings Book, Ankara 1: 411415 (in Turkish).

Mohammad, S.M. and A. Mosavi Johromi. 2011. Study of Nitrogen Fertilization Times Effects on New Sunflower Hybrids for Grain and Oil Yields, Advances in Environmental Biology, 5(7): 1968-1975.

Mojaddam, M., S. Lack and A. Shokuhfar. 2011. Effect of water stress and different levels of nitrogen on yield, yield components and wue of sunflower hybrid iroflor. Advances Environmental Biology, 5(10): 3410-3411.

Montemurro, F., D. De Giorgio, F. Fornaro, E. Scalcione, C. Vitti. 2007. İnfluence of climatic conditions on yields, $n$ uptake and efficiency in sunflower, Italian Journal of Agrometeorology, 2: 28-34.

Munir, M., A.W. Jasra and M. A. Mirza. 2007. Effects of feeding and management systems on body weight and reproductive performance of Balochiewes. Pakistan Vet.J., 27(3): 126-128.

Namvar, A., T. Khandan and M. Shojaei. 2012. Effects of bio and chemical nitrogen fertilizer on grain and oil yield of sunflower (Helianthus annuus L.) under different rates of plant density. Annals of Biology Research, 3(2): 1125-1131.

Nasim, W., A. Ahmad, H. M.Hammad, H.J. Chaudhary and M.F. H.Munis. 2012. Effect of nitrogen on growth and yield of sunflower under semi-arıd conditions of Pakistan. Pakistan Journal Botanic, 44(2): 639-648.

Osman, E.B.A. and M.M.M. Awed. 2010. Response of sunflower(helianthus annuus L.) to phosphorus and nitrogen fertilization under different plant spacing at new valley. Ass. Univ. Bull. Environ. Res., 13(1): 11-19.

Ozer, H., T. Polat and E. Ozturk. 2004. Response of irrigated sunflower (Helianthus annuus L.) hybrids to nitrogen fertilization: growth, yield and yield components. Plant Soil Environ, 50(5): 205-211.

Pandey, R.K., J.W. Marienville and A. Adum. 2000. Deficit irrigation and nitrogen effect on maize in a sahelian environment. 1. grain yield components. Agric. Water Management, 46: 1-13.

Sadras, V.O. 2006. The N:P stiochiometry of cereal, grain legume and oilseed crops. Field Crop Res., 95: 13-29.

Semerci, A. and İ. Meral. 2001. Sunflower production and problems in Turkey. The Turkish-Coop journal of Crop, 18: 54-61.

Smiderle, O.J., S.R.G. Silva and D.R. Schwengber. 2007. Productivity of sunflower cultivars in cerrado of roraima. produtividade de cultivares de girassol em cerrado de roraima. Documentos-Embrapa Soja 292: 67-70.

Steel, R.G.D and J.H. Torrie. 1980. Principles and Procedures of Statistics. Second Edition. McGraw Hill Book Company Inc. N.Y.

Thavaprakash, N. 2004. Effect of nitrogen and phosphorus levels and ratios on yield and quality of sunflower (Helianthus annus L.). Agriculture Science, 24(3): 186-189.

Tomar, H.P.S., K.S. Dadhwal and H.P. Singh. 1996. Oil content, oil and cake yield and protein content of sunflower (Helianthus annuus L.) as influenced by irrigation, nitrogen and phosphorus levels. Indian Journal of Soil Conservation, 24(3): 215-220.

Tripathi, H.P. and J.S. Sawhney. 1992. Nutrient uptake and quality of sunflower as influenced by irrigation and nitrogen levels. F. Crop Abst., 45(5): 3240.

Tuncturk, M., T. Eryigit and İ. Yilmaz. 2005. A research on determination of yield and some yield components of some sunflower varieties (Helianthus annuusL.) in Van-Erciş conditions. VI. Turkish Field Crops Congress, 5-9 September, 2005, pp. 41-44, Antalya, Turkey (in Turkish).

Ullah, S., A. Muhammad and S.M. Wazir. 2010. Effect of Hydropriming duration on growth and yield of maize landrace in Bannu, KPK, Pakistan. Pak. J. Pl. Sci., 16(2): 99105 . 